\title{
PERLINDUNGAN HUKUM ATAS TINDAK PIDANA PERDAGANGAN ORANG MELALUI UU NO. 21 TAHUN 2007 TENTANG TINDAK PIDANA PERDAGANGAN ORANG
}

\author{
Oleh : Dr. Dody Eko Wijayanto, SH, M.Hum
}

\begin{abstract}
Abstrak
Tindak pidana perdagangan Orang (Trafficking) merupakan perbuatan yang melanggar hak asasi manusia dan telah bertentangan dengan ketentuan perundangundangan yang berlaku di Indonesia.Munculnya berbagai kasus trafficking meliputi : tindakan perekrutan, pengangkutan, penampungan, pengiriman, pemindahan, atau penerimaan seseorang dengan ancaman kekerasan, penggunaan kekerasan, penculikan, penyekapan, pemalsuan, penipuan penyalahgunaan kekuasaan, penjeratan hutang, sehingga memperoleh persetujuan dari orang yang memegang kendali atas orang lain, untuk tujuan eksploitasi atau mengakibatkan orang tereksploitasi. Maraknya perdagangan anak berawal dari masalah ekonomi, sosial, politik dan budaya. Perdagangan anak bukan hanya menodai harkat dan martabat manusia, tetapi juga menodai ajaran agama.

Dari pemaparan di atas munculah suatu permasalahan yang menarik untuk diteliti sebagai jalan untuk mendeskripsikan dan menganalisis bagaimana UU NO. 21 tahun 2007 Tentang Pemberantasan Tindak Pidana Perdagangan Orang.

.Berdasarkan penelitian ini ditemukan bahwa tindak pidana perdagangan anak menurut Pasal 17 UU NO. 21 Tahun 2007 Tentang Pemberantasan Tindak Pidana Perdagangan Orang yang berbunyi: "Jika tindak pidana sebagaimana dimaksud dalam Pasal 2, Pasal 3, dan Pasal 4 dilakukan terhadap anak, maka ancaman pidananya ditambah $1 / 3$ (sepertiga)," yaitu dipidana penjara paling singkat 4 tahun dan paling lama 20 tahun dan pidana denda paling sedikit Rp.160.000.000,00 dan paling banyak Rp.800.000.000,00. Akan tetapi sampai sekarang masih banyak sekali kasus perdagangan anak yang terjadi, menurut penyusun itu terjadi dikarenakan kurang tegasnya penegakan hukum dan kurang beratnya sanksi yang dijatuhkan kepada pelakunya.
\end{abstract}

\section{Kata Kunci: Pidana, Perdangan Anak, UU N0. 21 Tahun 2007}

\section{Pendahuluan}

\section{A. Latar Belakang}

Perdagangan orang (trafiking) telah lama terjadi dimuka bumi ini dan merupakan tindakan yang bertentangan dengan harkat dan martabat manusia. Halini merupakan pelanggaran terhadap hak azasi manusia, harkat dan martabat manusia yang dilindungi berdasarkan Pancasila dan Undang-Undang Dasar 1945 Dimasa lalu perdagangan orang hanya dipandang sebagai pemindahan secara paksa ke luar negeri untuk tujuan prostitusi, kerja paksa secara ilegal sudah berlangsung lama.
Perdagangan manusia atau istilah Human Trafficking merupakan sebuah kejahatan yang sangat sulit diberantas dan disebut -sebut oleh masyarakat internasional sebagai bentuk perbudakan masa kini dan pelanggaran terhadap hak asasi manusia. Kejahatan ini terus menerus berkembang secara nasional maupun internasional. Dengan perkembangan dan kemajuan teknologi, informasi, komunikasi dan transportasi, maka semakin berkembang pula modus kejahatannya yang dalam beroperasinya sering dilakukan secara tertutup dan bergerak di luar hukum. Pelaku perdagangan orang ( trafficker) pun dengan cepat berkembang 
menjadi sindikasi lintas batas negara dengan cara kerja yang mematikan.

Perdagangan orang dapat mengambil korban dari siapapun, orang dewasa dan anak-anak, laki-laki maupun perempuan yang pada umumnya berada dalam situasi dan kondisi yang rentan. Modus yang digunakan dalam kejahatan ini sangat beragam dan juga memiliki aspek kerja yang rumit. Korban trafiking seringkali digunakan untuk tujuan eksploitasi seksual (pelacuran dan pedophilia), dipakai serta bekerja pada tempat-tempat kasar yang memberikan gaji rendah seperti buruh perkebunan, pembantu rumah tangga (PRT), pekerja restoran, tenaga penghibur, perkawinan kontrak, juga buruh anak.

Perlindungan hukum terhadap anak yang menjadi korban perdagangan orang diperoleh sejak proses pra peradilan, jalannya persidangan, maupun selesainya persidangan. Perlindungan hukum ini diberikan agar korban merasa tenang dan aman tanpa takut akan menjadi korban lagi. Perlindungan hukum bagi korban perdagangan orang harus sesuai dengan apa yang dimaksud dalam Undang - Undang No.21 Tahun 2007 Tentang Pemberantasan Tindak Pidana Perdagangan Orang dan korban juga berhak mendapat perlindungan hukum sesuai dengan peraturan perundang-undangan lainnya.

Dalam memberikan perlindungan bagi korban, hal ini tidak lepas dari masalah keadilan dan hak asasi manusia, di mana banyak peristiwa yang ditemukan korban kejahatan kurang memperoleh perlindungan hukum yang memadai. Perlu perhatian dari pemerintah secara serius, dan memang bukan merupakan pekerjaan yang sederhana untuk direalisasikan dalam upaya menegakan hukum. Oleh karena itu, dalam rangka memenuhi persyaratan dalam menyelesaikan studi Strata -1 penulis tertarik untuk menyusun penulisan hukum dengan judul

"Perlindungan Hukum Tindak Pidana Perdagangan Anak Melalui Pasal 17 UU No. 21 Tahun 2007"
B. Tujuan dan Manfaat

1. Untuk mengetahui tindak pidana perdagangan anak dalam UU NO. 21 Tahun 2007 Tentang Pemberantasan Tindak Pidana Perdagangan Orang.

2. Untuk mengetahui sanksi hukum bagi Pelaku tindak pidana Perdagangan anak dalam UU NO. 21 Tahun 2007 Tentang Pemberantasan Tindak Pidana Perdagangan Orang

\section{TINDAK PIDANA PERDAGANGAN ORANG DALAM UNDANG-UNDANG 21 TAHUN 2007 TENTANG TINDAK PIDANA PERDAGANGAN ORANG}

\section{A. Pengertian Perlindungan Hukum}

Makna perlindungan hukum dalam penelitian ini mencakup dua hal:

1. Perlindungan hukum terhadap anak yang menjadi korban perdagangan orang dalam arti jaminan hak -haknya yang diatur jelas dan tegas dalam perundang-undangan, yaitu segala kegiatan untuk menjamin dan melindungi anak dari hak-haknya agar dapat hidup, tumbuh, berkembang dan berpartisipasi, secara optimal sesuai dengan harkat dan martabat kemanusiaan, serta mendapat perlindungan dari kekerasan dan diskriminasi.

2. Perlindungan hukum dalam arti bagaimana hak anak diperhatikan dan diterapkan jaminan perlindungannya oleh aparat dalam penegakan hukum, yaitu bahwa aparat hukum berkewajiban dan bertanggungjawab untuk memberi perlindungan kepada korban dengan memperhatikan hak-haknya dan memberi jaminan perlindungan terhadap keamanan korban.

\section{B. Pengertian Tindak Pidana}

Menurut Undang-Undang Nomor 21 Tahun 2007 Tentang Pemberantasan Tindak Pidana Perdagangan Orang pasal 1, tindak pidana perdagangan orang adalah setiap tindakan atau serangkaian tindakan yang memenuhi unsur-unsur tindak pidana yang ditentukan dalam undang-undang ini.

\section{Rumusan Ancaman Pidana dalam UU} No. 21 Tahun 2007

a. Jenis sanksi/pidana

Jenis sanksi pidana yang terdapat dalam Pasal 2, 3, 4, 5, 6, 9, 19, 20, 21, 22, 23, dan 24 
Undang-Undang No.21 Tahun 2007 tentang Pemberantasan Tindak Pidana Perdagangan Orang adalah pidana pokok berupa penjara dan denda. Pidana tambahan terhadap pelaku tindak pidana perdagangan manusia diatur dalam Pasal tersendiri yaitu Pasal 15 yang berlaku terhadap pelaku yang berbentuk korporasi.

Seperti hal nya pidana tambahan, pengaturan tentang pemberian restitusi kepada korban secara langsung tidak diberikan dalam pasal-pasal tersebut, namun Undang-Undang No.21 Tahun 2007 telah mengatur dalam Pasal tersendiri yaitu Pasal 48.

\section{b. Lama pidana}

Lama pidana yang diancam oleh Pasal 2, 3, 4, 5, 6 Undang-Undang Nomor 21 Tahun 2007 adalah pidana penjarapaling singkat 3 (tiga) tahun dan paling lama 15 (lima belas) tahun, lama pidana yang diancam oleh Pasal 9 adalah pidana penjara paling singkat 1 (satu) tahun dan paling lama 6 (enam) tahun, lama pidana yang diancam oleh Pasal 19 dan 20 adalah pidana penjara paling singkat 1 (satu) tahun dan paling lama 7 (tujuh) tahun, lama pidana yang diancam oleh Pasal 21, 22, dan 23 adalah pidana penjara paling singkat 1 (satu) tahun dan paling lama 5 (lima) tahun sedangkan lama pidana yang diancam oleh Pasal 24 adalah pidana penjara paling singkat 3 (tiga) tahun dan paling lama 7 (tujuh) tahun.

\section{c. Sistem perumusan ancaman pidana}

Sistem perumusan pidana dalam Pasal 2, 3, 4, 5, 6, 19, 20, 21, 22, 23, dan 24 UndangUndang Nomor 21 Tahun 2007 adalah berupa kumulatif (penjara dan denda). Sistem perumusan kumulatif bersifat kaku dan imperative. $^{1}$ Sifat imperatif/kumulatif tidak member keleluasaan kepada hakim untuk memilih dan sulit diterapkan apabila hakim akan menjatuhkan pidana kepada korporasi sebagai pelaku tindak pidana, karena dengan adanya sistem kumulatif maka terhadap korporasi sebagai pelaku perdagangan manusia,

${ }^{1}$ Ibid., Hal 207 hakim juga "harus" menjatuhkan pidana penjara selain pidana denda.

Dapat dikatakan bahwa pasal-pasal tersebut merupakan bentuk perlindungan secara tidak langsung. Selain memberikan perlindungan terhadap korban perdagangan manusia secara tidak langsung (abstrak). Undang-Undang Nomor 21 Tahun 2007 tentang Pemberantasan Tindak Pidana Perdagangan Orang juga memberikan perlindungan secara langsung (konkret) atau yang dapat dirasakan secara langsung oleh korban perdagangan manusia. Perlindungan secara langsung tersebut diatur dalam bab tersendiri yaitu bab 5, Pasal 43-55, mengenai perlindungan saksi dan korban.

\section{Korban Kejahatan}

Pasal 1 ayat (1) UU No. 21 Tahun 2007, disebutkan pengertian korban, yaitu: "Korban adalah seseorang yang mengalami penderitaan psikis, mental, fisik, seksual, ekonomi, dan/atau sosial, yang diakibatkan tindak pidana perdagangan orang”

Secara umum yang dimaksud dengan korban adalah mereka yang menderita jasmaniah dan rohaniah sebagai akibat tindakan orang lain yang mencari pemenuhan kepentingan diri sendiri atau orang lain yang bertentangan dengan kepentingan dan hak asasi yang menderita

\section{Perdagangan Orang}

Pasal 1 ayat (1) Bab I tentang Ketentuan Umum Undang Undang nomor 21 tahun 2007 tentang Pemberantasan Tindak Pidana Perdagangan Orang menyebutkan “ Perdagangan orang adalah tindakan perekrutan, pengangjutan, penampungan, pengiriman, pemindahan atau penerimaan seseorang dengan ancaman kekerasan, penggunaan kekerasan, penculikan, penyekapan, pemalsuan, penipuan, penyalahgunaan kekuasaan atau posisi rentan, penjeratan hutang atau member bayaran atau manfaat, sehingga memperoleh persetujuan dari orang yang memegang kendali atas orang lain tersebut, baik yang dilakukan di dalam 
Negara maupun antar negara, untuk tujuan eksploitasi atau mengakibatkan orang terekspolitasi"

\section{E. Modus Operandi Perdagangan Manusia}

Pola kejadian perdagangan manusia (yaitu, apa yang terjadi, bagaimana terjadinya dan terhadap siapa terjadi) sangat bervarariasi dari satu tempat tertentu dengan tempat lainnya. Ada beberapa karakteristik pokok pola perdagangan manusia yang terjadi sekarang

1. Perdagangan manusia terjadi untuk berbagai tujuan akhir termasuk layanan rumah tangga, kawin paksa dan tenaga kerja yang diperas tenaganya dengan bayaran rendah. Pekerjaan seksual paksa merupakan hasil akhir yang paling jelas dari perdagangan manusia, tetapi sulit dibuktikan bahwa hal ini merupakan yang paling lazim.

2. Perdagangan manusia terjadi di dalam maupun antar negara.

3. Pelaku perdagangan manusia memakai berbagai cara rekrutmen. Penculikan secara langsung merupakan cara yang jarang dilaporkan dan seringkali sulit diperiksa secara obyektif. Perdagangan manusia pada anak-anak pada umumnya meliputi tindakan pembayaran yang dilakukan kepada orang tua atau wali untuk bekerjasama dan sering hal ini disertai dengan tindak penipuan berkaitan dengan pekerjaan atau posisi di masa yang akan datang.

4. Stereotip "coerced innocent" (dugaan telah terjadi penyekapan) terlalu sederhana untuk mencerminkan kenyataan dari kebanyakan situasi perdagangan manusia yang diketahui. Kebanyakan pelaku perdagangan manusia memakai berbagai derajat kecurangan atau penipuan, daripada kekerasan langsung, guna menjalin kerjasama awal dengan orang yang mengalami trafiking manusia. Keadaan yang lazim dilaporkan mencakup anak perempuan atau perempuan muda yang ditipu mengenai biaya (dan kondisi pengembalian) jasa migrasi yang ditawarkan kepadanya, jenis pekerjaan yang hendak dilakukannya di luar negeri dan /atau kondisi pekerjaan yang diharapkannya.

5. Menurut definisi, orang yang mengalami perdagangan manusia akhirnya masuk dalam suatu keadaan yang tidak dapat dilepaskannya. Pelaku perdagangan manusia dan kaki tangannya menggunakan beragam cara untuk mencegah korban melarikan diri, termasuk pemakaian ancaman dan kekerasan, intimidasi, penyekapan dan penahanan sejumlah dokumen pribadi.

\section{SANKSI HUKUM BAGI PELAKU TINDAK PIDANA PERDAGANGAN ORANG DALAM UU NO. 21 TAHUN 2007 TENTANG PEMBERANTASAN TINDAK PIDANA PERDAGANGAN ORANG}

A. Latar Belakang lahirnya UU NO. 21 Tahun 2007 Tentang Pemberantasan Tindak Pidana Perdagangan Orang.

Mengenai kejahatan perdagangan manusia sebelum lahirnya UU No.21 tahun 2007 tentang pemberantasan tindak pidana perdagangan orang (PTPPO), diatur secara tegas dalam KUHP pasal 297 namun pasal tersebut ancamannya terlalu ringan sehingga tidak mencerinkan adanya suatu pemebrian efek jera kepada pelaku tindak pidana perdagangan orang.

Fenomena tentang perdagangan orang telah ada sejak tahun 1949 yaitu sejak ditandatangani Convention on Traffic in Person. Hal ini kemudian berkembang ketika banyak laporan tentang terjadinya tindakan perdagangan perempuan pada Beijing Plat Form of Action yang dilanjutkan dengan Convention on Elimination of All Form of Descrimination Agains Women CEDAW) dan telah diratifikasi oleh Indonesia dengan Undang-Undang (No. 7 tahun 1984 tentang Penghapusan segala Bentuk Deskriminasi terhadap Perempuan. Kemudian dipertegas dalam agenda Global Alliance Agains Traffic in Women (GAATW) di Thailand tahun 1994.

Peraturan Pemerintah No. 2 Tahun 2002 tentang Tata Cara Perlindungan terhadap Korban dan Saksi dalam Pelanggaran Hak Asasi Manusia yang Berat: Korban adalah orang perorangan atau kelompok orang yang mengalami penderitaan sebagai akibat pelanggaran hak asasi manusia yang berat yang memerlukan perlindungan fisik dan mental dari ancaman, gangguan, terror, dan kekerasan pihak manapun. 
Melihat data yang ada diatas terlihat jelas bahwa perlindungan yang diberikan oleh pemerintah sebelum di undangkannya UU No. 21 tahun 2007 sangatlah buruk. Karena dari data yang ada sejak tahun 1993 sampai dengan 2002 banyak sekali kasus-kasus perdagangan orang yang tidak dapat di cegah bahkan sampai diselesaikan, karena aturan yang dipakai untuk menjerat pelaku kejahatan perdagangan orang yaitu pasal 297 KUHP cenderung tidak mampu menjerat para pelaku perdagangan orang (human trafickking), karena cakupannya terlalu sempit dan rancu.

Setelah lahirnya UU No.21 tahun 2007 tentang pemberantasan tindak pidana perdagangan orang (PTPPO), pemerintah telah lebih memfokuskan diri untuk memberikan perlindungan terhadap korban perdagangan orang. Sebagaimana yang termuat dalam BAB $\mathrm{V}$ tentang perlindungan saksi dan korban dari pasal 43 sampai dengan pasal 55, yang mana dalam pasal-pasal tersebut menguraikan tentang hak-hak dari korban dan juga model perlindungan yang dapat diberikan kepada korban kejahatan perdagangan orang.

Pada dasarnya bentuk-bentuk atau model perlindungan terhadap korban kejahatan dapat juga diberikan kepada korban tindak pidana perdagangan orang, untuk lebih mendalami bentuk perlindungan terhadap korban kejahatan perdagangan orang, maka terdapat beberapa bentuk atau model perlindungan yang dapat diberikan kepada korban yaitu :

1. Pemberian Restitusi dan Kompensasi.

2. Layanan Konseling dan Pelayanan/Bantuan Medis.

3. Bantuan Hukum

4. Pemberian Informasi

Pemberian informasi kepada korban atau keluarganya berkaitan dengan proses penyelidikan dan pemeriksaan tindak pidana yang dialami korban.

Selain perlindungan yang dimaksud dalam UU No.21 tahun 2007, undang-undang tersebut juga memberikan hak-hak kepada korban kejahatan perdagangan orang yang berupa: a. Hak kerahasiaan identitas korban tindak pidana perdagangan orang dan keluarganya sampai derajat kedua. (Pasal 44).

b. Hak untuk mendapat perlindungan dari ancaman yang membahayakan diri, jiwa dan/atau hartanya (Pasal 47).

c. Hak untuk mendapat restitusi (Pasal 48)

d. Hak untuk memperoleh rehabilitasi kesehatan, rehabilitasi sosial, pemulangan dan reintegrasi sosial dari pemerintah. (Pasal 51)

e. Korban yang berada di luar negeri berhak dilindungi dan dipulangkan ke Indonesia atas biaya negara. (Pasal 54).

\section{B. Sistematika dan Penjelasan UU NO. 21 Tahun 2007 Tentang Pemberantasan Tindak Pidana Perdagangan Orang.}

\section{Kualifikasi Delik}

Dalam Undang-Undang No.21 Tahun 2007 tentang Pemberantasan Tindak Pidana Perdagangan Orang, tidak ada penegasan kualifikasi antara delik kejahatan maupun delik pelanggaran.

Mungkin tidak ditegaskannya kualifikasi delik perdagangan manusia sebagai kejahatan, karena pembuat Undang-Undang sudah tidak lagi membedakan akibat hukum atau pemidanaan untuk "percobaan" dan "pembantuan", yaitu diancam pidana yang sama dengan pelaku perdagangan manusia atau pelaku delik (Pasal 10 Undang-Undang No.21 Tahun 2007). Padahal akibat hukum dari pembedaan "kejahatan dan "pelanggaran" bukan hanya pada masalah percobaan dan pembantuan, tetapi juga pada masalah lain seperti dalam hal ada "concursus", "daluwarsa penuntutan dan pelaksanaan pidana", berlakunya "asas nasional aktif" dalam Pasal 5 (1) ke-2 KUHP. ${ }^{2}$

Pasal 10 Undang-Undang No.21 Tahun 2007 ini memang mengatur tentang delik percobaan dan pembantuan, namun hanya untuk tindak pidana sebagaimana yang diatur dalam Pasal 2, Pasal 3, Pasal 4, Pasal 5 dan

\footnotetext{
${ }^{2}$ Barda Nawawi Arief, Masalah, Op.cit, Hal
} 
Pasal 6 Undang-Undang tersebut, sedangkan untuk Pasal 19, 20, 21, 22, 23, dan 24, tidak ada pengaturan mengenai delik-delik tersebut.

2. Rumusan Pertanggungjawaban Pidana (Pelaku).

Pasal 2, 3, 4, 5, 19 memang tidak menyatakan secara eksplisit unsur sengaja atau kealpaan, namun karena ada unsur " untuk tujuan", unsur "dengan maksud" dan unsur "untuk mempermudah" yang merupakan keinginan yang disengaja oleh pelaku yang dikehendaki akan terjadi, sedangkan pada Pasal 9 ada unsur "berusaha" yang merupakan tindakan yang disengaja oleh pelaku dan memiliki tujuan yang dikehendaki akan terjadi (orang yang digerakkan oleh pelaku akan melakukan tindak pidana perdagangan manusia) maka dapat dikatakan bahwa pertanggungjawaban pidana dalam Pasal 2, 3, 4, 5, 9 dan 19 Undang-Undang No.21 tahun 2007 menganut prinsip pertanggungjawaban berdasarkan kesalahan (Liability based on fault)

\section{UNSUR DAN FAKTOR PERDAGANGAN ORANG}

1. Unsur

a. Proses (rekrutmen, pengangkutan, pemindahan, melabuhkan atau menerima orang)

b. Tujuan (eksploitasi yang mencakup, minimal, eksploitasi pelacuran orang lain atau bentuk-bentuk eksploitasi lainnya, kerja atau pelayanan paksa, perbudakan atau praktek-praktek yang mirip dengan perbudakan, penghambaan atau pemindahan organ tubuh)

2. Faktor Pendorong Perdagangan Manusia

a. Kurangnya pengetahuan tentang akibat dari trafiking

b. Faktor ekonomi

c. Adanya izin dari orang tua

d. Adanya keinginan untuk mengikuti perkembangan modern/zaman

\section{KESIMPULAN DAN SARAN}

\section{A. Kesimpulan}

1. Perlindungan hukum terhadap korban perdagangan orang pengaturannya di dalam Undang-Undang No. 21 tahun 2007 tentang Pemberantasan Tindak Pidana Perdagangan Orang yang meliputi kerahasian identitas korban dan keluarganya, disediakan ruangan pelayanan khusus pada kantor kepolisian guna melakukan pemeriksaan di tingkat penyidikan, dibentuk pusat pelayanan terpadu.

2. Perlindungan anak terhadap Tindak Pidana Trafficking dalam undang-undang ini hanya diatur dalam beberapa pasal yaitu Pasal 2, Pasal 3, Pasal 4, Pasal 5, Pasal 6 dan Pasal 17. Pengaturan mengenai perlindungan anak terhadap tindak pidana perdagangan orang secara spesifik sudah diatur oleh peraturan perundang-undangan sebelumnya yaitu dalam KUHP, Undang-undang Nomor 39 Tahun 1999 tentang Hak Asasi Manusia dan Undang-undang Nomor 23 Tahun 2002 tentang Perlindungan Anak. Namun dalam peraturan perundangan sebelumnya, tidak memberikan definisi mengenai perdagangan orang dan perbuatan apa saja yang dapat digolongkan sebagai tindak pidana trafficking. Diundangkannya Undangundang No.21 Tahun 2007 tentang Pemberantasan Tindak Pidana Perdagangan Orang memberikan definisi mengenai perdagangan orang dan perbuatan apa saja yang bisa digolongkan sebagai tindak pidana trafficking. Dengan demikian tidak menimbulkan interprestasi lain tentang definisi dan perbuatan yang tergolong dalam tindak pidana trafficking

\section{B. SARAN}

1. Bagaimanapun himpitan ekonomi yang melanda, orang tua tidak boleh menjual anaknya, karena alasan tidak mampu mencukupi kehidupannya ataupun alasan yang lain. Karena anak adalah amanat Allah yang harus senantiasa dilindungi, dipelihara, dan dididik serat dibina dengan penuh tanggung jawab.

2. Penegakan supremasi hukum tanpa pandang bulu. Hukum harus ditegakkan tanpa memandang atribut keduniaan 
karena hukum yang ditegakkan akan membawa keadilan dan ketentraman bagi masyarakat. Lemahnya penegakan akan menimbulkan kekacauan dan gejolak sosial yang mengarah pada tindakan kekerasan dan anarkisme. Terutama dalam kasus tindak pidana perdagangan anak, pengadilan harus tegas dalam memberi sanksi bagi pelaku tindak pidana perdagangan anak bila terbukti salah. Karena dampak dari perdagangan anak sangat merugikan dan membahayakan bagi kehidupan dan masa depan anak.

\section{Daftar Pustaka}

Andi Hamzah, Asas-asas Hukum Pidana, Cetakan 1, Jakarta: Yarsif Watampone, 2005.

Anton Bakker \& Achmad Charris Zubair, Metodologi Penelitian Filsafat, Yogyakarta: Kanisius, 1996.

Arif Gosita, Masalah Korban Kejahatan, Jakarta: Bhuana Ilmu Populer, 2004.

Barda Nawawi Arief, Kebijakan Legislatif dalam Penanggulangan Kejahatan dengan Pidana Penjara, Cetakan Ketiga, Semarang: Badan Penerbit Universitas Diponegoro, 2000.

Chairul Huda, Dari Tiada Pidana Tanpa Kesalahan Menuju kepada Tiada Pertanggungjawaban Pidana Tanpa Kesalahan, Cetakan Kedua, Jakarta: Kencana, 2006.

Daliyo J.B. 1992, et.al., Pengantar Hukum Indonesia: Buku Panduan Mahasiswa, Jakarta: PT. Gramedia Pustaka Utama.

Dellyana Shanty, 1988, Wanita dan Anak di Mata Hukum, Yogyakarta: Liberty.

Dirdjosisworo Soedjono, 1988, Pengantar Ilmu Hukum, Jakarta: CV. Rajawali.

Gosita Arif. 1989. Masalah Perlindungan Anak, Jakarta: Akedemika Presindo.

Henny Nuraeny, Tindak Pidana Perdagangan Orang, Jakarta: Sinar Grafika, 2011.
Irawati Harsono, Penanganan Polri Terhadap Kasus Perdagangan Anak, Jakarta Raya: Universitas Bhayangkara, 2004.

Kitab Undang-Undang hukum Pidana, Diterjemahkan oleh Moeljatno, Cetakan 22, Jakarta: Sinar Grafika, 2003.

Muladi dan Barda Nawawi A., 1984, Teoriteori Dan Kebijakan Pidana,

Sianturi, S. R., Asas-Asas Hukum Pidana di Indonesia dan Penerapannya, Jakarta: Alumni AHAEM-PTHAEM, 1986.

Soeharto, 1993, Hukum Pidana Materiil; Unsur-unsur Obyetif Sebagai Dasar Dakwaan, Jakarta: Sinar Grafika.

Soemitro Irma Setyowati. 1990. Aspek Hukum Perlindungan Anak, Jakarta: Bumi Aksara

Undang-Undang Nomor 13 Tahun 2006 tentang Perlindungan Saksi dan Korban.

Undang-Undang Nomor 23 Tahun 2003 tentang Perlindungan Anak.

Undang-Undang RI No. 21 Tahun 2007 Tentang Pemberantasan Tindak Pidana Perdagangan Orang. 


\title{
PENYELESAIAN SENGKETA HAK CIPTA MENURUT UNDANG-UNDANG NO.19 TAHUN 2002 TENTANG HAK CIPTA
}

\author{
Oleh : Jatmiko Winarno, SH, MH
}

\begin{abstract}
Abstrak
Praktek perdagangan musik dan lagu yang melanggar hak cipta dituangkan dalam bentuk VCD dan DVD di lingkungan jalan marak dilakukan. Hal ini tentunya mengundang permasalahan dalam konteks pelanggaran hak cipta dan membutuhkan langkah-langkah hukum untuk meminimalisir hal tersebut. Sejalan dengan itu, telah dilakukan penelitian yang berhubungan dengan hal tersebut dengan menggunakan metode penelitian hukum empirik. Hasilnya, terdapat sejumlah permasalahan atas pelanggaran hak cipta baik secara perdata dan pidana. Langkah penyelesaian yang dilaksanakan berupa sosialisasi dan penegakan hukum.
\end{abstract}

\section{Kata kunci : Hak Cipta, Undang - undang Nomor 19 Tahun 2002.}

\section{Pendahuluan}

Suatu hasil karya kreatif yang akan memperkaya kehidupan manusia akan dapat menghabiskan waktu bertahun-tahun untuk mengembangkannya. Apabila si pencipta karya-karya tersebut tidak diakui sebagai pencipta atau tidak dihargai, karya-karya tersebut mungkin tidak akan pernah diciptakan sama sekali.

Hak Atas Kekayaan Intelektual (selanjutnya disebut HAKI) merupakan hak atas kekayaan yang timbul atau lahir dari kemampuan intelektual manusia. HAKI memang menjadikan karya-karya yang timbul atau lahir karena adanya kemampuan intelektual manusia yang harus dilindungi. Kemampuan intelektual manusia dihasilkan oleh manusia melalui daya, rasa, dan karsanya yang diwujudkan dengan karyakarya intelektual. Karya-karya intelektual juga dilahirkan menjadi bernilai, apalagi dengan manfaat ekonomi yang melekat sehingga akan menumbuhkan konsep kekayaan terhadap karya-karya intelektual.

UUHC membawa kemajuan baru dalam perlindungan hak tersebut, yang meliputi perlindungan terhadap buku, program komputer, pamflet, sampul karya tulis yang diterbitkan, dan semua hasil karya tulis lain, ceramah, kuliah, pidato, lagu atau musik dengan atau tanpa teks, drama, tari, koreografi, pewayangan dan pantomim, seni rupa dalam segala bentuk, arsitektur, peta, seni batik, fotografi, sinematografi, terjemahan, tafsir, saduran, bunga rampai, data base dan karya lain dari hasil pengalihwujudan.

Secara spesifik, Undang-undang ini memuat beberapa ketentuan baru, antara lain:

1. Database merupakan salah satu ciptaan yang dilindungi;

2. Penggunaan alat apapun baik melalui kabel maupun tanpa kabel, termasuk media internet untuk pemutaran produk-produk cakram optik (optical disc) melalui media radio, media audio visual dan/ atau sarana telekomunikasi;

3. Penyelesaian sengketa oleh pengadilan niaga, arbitrase atau alternatif penyelesaian sengketa;

4. Penetapan sementara pengadilan untuk mencegah kerugian lebih besar bagi pemegang hak ;

5. Batas waktu proses perkara perdata di bidang hak cipta dan hak terkait baik di pengadilan niaga maupun di Mahkamah Agung ;

6. Pencantuman hak informasi manejemen elektronik dan sarana kontrol teknologi;

7. Pencantuman mekanisme pengawasan dan perlindungan terhadap produkproduk yang menggunakan sarana berteknologi tinggi;

8. Ancaman pidana atas pelanggaran Hak Terkait;

9. Ancaman pidana dan denda minimal; 
10. Ancaman pidana tetap terhadap perbanyakan penggunaan program komputer untuk kepentingan komersial secara tidak sah dan melawan hukum.

\section{Metode Penelitian}

\section{Type Penelitian}

Sesuai dengan judul dan materi yang di bahas maka penelitian ini adalah penelitian yuridis normatif, metode penelitian hukum normatif adalah suatu prosedur penelitian ilmiah untuk menemukan kebenaran berdasarkan logika keilmuan hukum dari sisi normatif. Oleh karena itu penelitian hukum ini di fokuskan untuk mengkaji penelitian hukum tentang upaya hukum penentuan dan penyelesaian sengketa hak ciptaan.

\section{Pendekatan Masalah}

Oleh karena type penelitian yang di gunakan adalah type penelitian yuridis normatif, maka pendekatan masalah yang digunakan adalah pendekatan perundang-undangan (Statute Approach), pendekatan tersebut melakukan pengkajian pengaturan perundang-undangan yang berhubungan dengan pokok permasalahan. Selain itu juga digunakan pendekatan analisis (Analitical Approach), Pendekatan ini maksudnya menganalisa tentang penentuan dan penyelesaian sengketa hak ciptaan.

3. Bahan Hukum

a. Bahan Hukum Primer

Merupakan bahan hukum yang bersifat autoritatif artinya mempunyai otoritas bahan hukum primer terdiri dari perundang-undangan.

b. Bahan Hukum Sekunder

Berupa semua publikasi tentang hukum yang bukan merupakan dokumen-dokumen resmi, yaitu berupa buku teks, kamus-kamus hukum, jurnaljurnal hukum dasar,komentar-komentar atas putusan pengadilan.

4. Prosedur Pengumpulan Bahan Bahan

Baik bahan primer maupun bahan sekunder dikumpulkan berdasarkan topik permasalahanyang telah dirumuskan dan diklarifikasi menurut sumber dan hirarkinya untuk di kaji secara komprehensif.

5. Pengolahan dan Analisis Bahan Hukum

Adapun bahan yang diperoleh dalam penelitian studi kepustakaan aturan perundang-undangan, yang penulis uraikan dan dihubungkan sedemikian rupa, sehingga di sajikan dalam penulisan yang lebih sistematis guna menjawab perumusan masalah yang dirumuskan. Cara pengolahan data dilakukan secara deduktif yakni menarik kesimpulan dari suatu permasalahan yang bersifat umum terhadap permasalahan kongkrit yang dihadapi.

\section{Manfaat Penelitian}

Penulis berharap bahwa kegiatan penelitian dalam penulisan hukum ini akan bermanfaat bagi penulis maupun orang lain.Adapun manfaat yang dapat di peroleh dari penulisan hukum ini antara lain :

1. Manfaat Teoritis

a. Penelitian ini diharapkan dapat memberikan manfaat pada pengembangan ilmu pengetahuan di bidang ilmu hukum pada umumnya dan dalam rana hukum perdata khususnya.

b. Hasil penelitian ini diharapkan dapat memperkaya referensi dan literatur dalam dunia kepustakaan tentang upaya hukum terhadap penentuan dan penyelesaian sengketa hak ciptaan menurut undang-undang no.19 tahun 2002 tentang hak cipta.

c. Hasil penelitian ini dapat digunakan sebagai bahan untuk membuat suatu keputusan tentang penentuan dan penyelesaian sengketa hak ciptaan menurut undang-undang no.19 tahun 2002 tentang hak cipta.

2. Manfaat Praktis 
a. Menjadi wahana bagi penulis untuk mengembangkan penalaran membentuk pola pikir ilmiah sekaligus untuk mengetahui kemampuan penulis dalam menerapkan ilmu yang diperoleh.

b. Untuk memberikan jawaban atas permasalahan yang di teliti.

\section{Pembahasan \\ 1. Penentuan Pencipta dan Pemegang Hak Cipta \\ Konsep perlindungan hak cipta} adalah melindungi pencipta dan hasil ciptanya, dimana dalam UUHC terdapat perbedaan antara pencipta dan pemegang hak cipta. Begitu pula dengan lagu atau musik, dimana didalamnya terdapat unsur pencipta dan pemegang hak cipta.

Pencipta musik atau lagu adalah seseorang atau beberapa orang secara bersama-sama yang atas inspirasinya lahir suatu ciptaan musik atau lagu berdasarkan kemampuan pikiran, imajinasi, kecekatan, keterampilan atau keahlian yang dituangkan dalam bentuk yang khas dan bersifat pribadi, yang dalam istilah lain dikenal sebagai komposer

Menurut Pasal 1 huruf 2 UUHC, disebut sebagai pencipta apabila "Seorang atau beberapa orang secara bersama-sama yang atas inspirasinya melahirkan suatu ciptaan berdasarkan kemampuan pikiran, imajinasi, kecekatan, keterampilan atau keahlian yang dituangkan kedalam bentuk yang khas dan bersifat pribadi."

Sedangkan pemegang hak cipta menurut pasal 1 huruf 4 adalah pencipta sebagai pemilik hak cipta atau pihak yang menerima hak tersebut dari pencipta atau pihak lain yang menerima hak tersebut.

Berdasarkan pengertian diatas pencipta dapat sekaligus sebagai pemegang hak cipta dalam hal hak cipta tersebut tidak dialihkan kepada pihak lain, akan tetapi pemegang hak cipta belum tentu ia sebagai pencipta karena dapat dimungkinkan pemegang hak cipta menerima pengalihan hak dari pencipta atau membeli hak tersebut dari pencipta.

Hak cipta sebagai benda bergerak yang immaterial merupakan obyek hukum perdata (dalam hukum kebendaan) walaupun sesungguhnya hak cipta merupakan obyek tidak berwujud ( intiangible), sehingga pada gilirannya hak cipta dapat dimilki sebagai mana layaknya hak kebendaan ( tangible property ) lainnya.

Hak cipta adalah kekayaan personal maka hak cipta dapat disamakan dengan bentuk kekayaan yang lain, yakni dapat dialihkan. Secara khusus pengaturan mengenai pengalihan hak dan hukum hak cipta diatur dalam Pasal 3 ayat (1) UUHC, bahwa hak cipta dianggap sebagai benda bergerak maka hak ciptanya dapat dipindah tangankan, di lisensikan, dialihkan, dijualbelikan oleh pemilik atas pemegang haknya.

\section{Proses Penyelesaian Sengketa Hak Cipta \\ Dalam UUHC telah diatur} perlindungan hukum terhadap pemegang hak cipta atas lagu atau musik. Perlindungan hukum yang dimaksud diberikan kepada pemegang hak cipta musik atau lagu atas perbuatan pihak lain yang dengan tanpa hak mengumumkan atau memperbanyak ciptaan musik atau lagu. Perbuatan pengumuman ini sendiri adalah pembacaan, pameran, penjualan, pengedaran atau penyebaran suatu ciptaan dengan menggunakan alat apapun, termasuk media internet atau melakukan dengan cara apa pun sehingga suatu ciptaan dapat dibaca, didengar atau dilihat orang lain.

Pemegang hak cipta dilindungi baik secara pidana maupun perdata. Dari sisi pidana, perlindungan hukum bagi pemegang hak cipta (musik atau lagu) diatur dalam Pasal 72 Ayat (1) UUHC yang menentukan bahwa barang siapa dengan sengaja dan tanpa hak melakukan perbuatan sebagaimana dimaksud dalam Pasal 2 Ayat (1) atau Pasal 49 Ayat (1) dan Ayat (2) dipidana dengan pidana penjara masingmasing paling singkat satu bulan dan/atau denda paling sedikit $\mathrm{Rp} 1.000 .000,-$ atau pidana penjara paling lama 7 tahun dan/atau denda paling banyak Rp 5 milliar. Selanjutnya dalam Ayat (2) ditentukan bahwa barang siapa dengan sengaja menyiarkan, memamerkan, mengedarkan 
atau menjual kepada umum suatu ciptaan atau barang hasil pelanggaran hak cipta atau hak terkait sebagaimana dimaksud pada Ayat (1) dipidana dengan pidana penjara paling lama 5 tahun dan/atau denda paling banyak Rp 500.000.000,-

Sedangkan Perlindungan hukum dari sisi perdata tidak hanya dilakukan dengan gugatan melalui Pengadilan Niaga akan tetapi bisa diselesaikan melalui alternatif penyelesaian sengketa. Demi kepentingan bisnis dengan mengingat keuntungan yang diperoleh melalui penyelesaian sengketa di luar pengadilan, UUHC memungkinkan untuk menyelesaikan perselisihan di bidang hak cipta (khususnya lagu) melalui arbitrase dan sejumlah alternatif penyelesaian sengketa lainnya berdasarkan UUHC dimana alternatif penyelesaian sengketa lainnya tersebut antara lain adalah konsultasi, negosiasi, mediasi, konsiliasi, atau penilaian ahli.

\section{Kendala dalam penanganan tindak pidana hak cipta yang terjadi}

Hukum sebagai serangkaian norma yang memiliki ukuran pasti dan daya paksa dalam pelaksanaanya senantiasa berjalan berdampingan dalam kehidupan manusia. Hukum berfungsi melindungi dari kepentingan lain yang merugikan. Hukum mengidealkan satu keseimbangan dalam keteraturan antara hak dan kewajiban.

Secara perspektif Internasional Persetujuan tentang Aspek-aspek Hak Atas Kekayaan Intelektual (HAKI) yang terkait dengan perdagangan (agreement on Trade Related Aspects of Intellectual Property Rights;TRIPs) yang merupakan bagian yang tidak terpisahkan dari Persetujuan Pembentukan Organisai Perdagangan Dunia (Agreement Establising the World Trade Organisation) telah diratifikasi berdasarkan Udang-Undang Nomor 7 Tahun 1994. implikasinya, bahwa Indonesia harus melakukan harmonisasi dengan ketentuanketentuan yang ada didalamnya.

\section{Penutup}

\section{A. Kesimpulan}

Berdasarkan bab-bab tersebut diatas, maka penulis menyimpulkan sebagai berikut:
1. Hak Cipta merupakan salah satu bentuk dari hak atas kekayaan intelektual pada dasarnya telah mendapatkan perlindungan dari secara hukum baik melalui hukum nasional maupun hukum Internasional. Perlindungan terhadap hak cipta berfungsi untuk melindungi hakhak yang dimiliki oleh pencipta atas karya ciptaannya, hak cipta juga melindungi potensi pencipta karena eksistensi terhadap kemampuan yang dimiliki seorang pencipta untuk menciptakan suatu karya cipta dan karya ciptaannya tetap terjaga. Dengan adanya hak cipta seorang pencipta tetap memiliki semangat untuk menciptakan sesuatu karena ia merasa aman dan nyaman sehubungan dengan adanya perlindungan terhadap hak yang ia miliki sebagai seorang pencipta.

2. Penyelesaian sengketa yang diambil oleh pihak pertama dengan pihak kedua adalah alternatif penyelesaian sengketa dengan jenis negosiasi. Dimana dalam negosiasi ini pihak pertama menggunakan pengacaranya untuk mewakili mereka yang kemudian melakukan kesepakatan dengan pihak kedua. Hasil kesepakatan tersebut kemudian didaftarkan di pengadilan paling lama 30 hari sejak penandatanganan agar mempunyai kekuatan ekselutorial berdasarkan Pasal 6 ayat (7) UU No. 30 Tahun 1999. Hasil kesepakatan tersebut wajib segera dilaksanakan paling lambat 30 hari sejak didaftarkan dke pengadilan berdasarkan Pasal Pasal 6 ayat (8) UU No. 30 Tahun 1999.

B. Saran

1. Seharusnya kita berhati-hati apabila akan menyiarkan, mengedarkan ataupun menyanyikan lagu milik orang lain untuk tujuan komersil. Kita harus berpikir bahwa apa yang kita siarkan, edarkan atau nyanyikan adalah hak cipta orang lain yang tentunya bisa menimbulkan permasalahan dikemudian hari, seperti adanya tuntutan ganti rugi. Oleh karena itu apabila kita akan menyiarkan, mengedarkan atau 
menyanyikan lagu milik orang lain, kita harus terlebih dahulu meminta perizinan kepada pencipta maupun pemegang hak ciptanya.

2. Apabila memang terjadi perselisihan mengenai hak cipta hendaknya ditempuh jalur alternatif penyelesaian sengketa yang prosedurnya lebih mudah dan tidak mengeluarkan banyak biaya.

\section{DAFTAR PUSTAKA}

Abdul Kadir Muhammad, Kajian Hukum Ekonomi Hak Intelektual, PT.Citra Aditya Bakti, Bandung 2001.

Bahan Bacaan Sujud Margono,Hukum Dan Perlindungan Hak Cipta, CV Novindo Pustaka Mandiri, Jakarta, 2003.

Djumhana dan R. Djubaedilah IV,Hak Milik Intelektual (sejarah, Teori, dan

Munir Fuady, Arbitrase Nasional (Alternatif Penyelesaian Sengketa ),PT. Citra Aditya Bakti, Bandung, 2000. Abdulkadir Muhammad, Kajian Hukum Ekonomi Hak Intelektual, PT.Citra Adtya Bakti, Bandung,2001.

OK. Saidin, Aspek Hukum Hak Kekayaan Intelektual,PT.Raja Grafindo Persada, Jakarta, 2001.

Prakteknya di Indonesia), Cetakan kedua, PT. Citra Aditya Bakti, Bandung, 2003,

Setiawan, Aneka Masalah Hukum dan Hukum Acara Perdata, Alumni Bandung, Bandung, 1992.

Sri Soemantri, Prospek dan Pelaksanaan Arbitrase di Indonesia,PT. Citra Aditya Bakti, Bandung, 2001.

Sudargo Gautama, Perkembangan Arbitrase Dagang Indonesia,Eresco, Bandung, 1989 .

Tim Penyusun Kamus Pustaka Pembinaan dan Pengembangan bahasa, kamus besar bahasa Indinesia, Balai Pustaka, Jakarta 1988.
Zae ,Berbisnis nada jangan sampai di penjara.www.inovasi.lipi.go.id/hki/ne ws, 2003.

\section{PERUNDANG-UNDANGAN :}

Undang - undang Nomor 19 Tal

perubahan atas Undang-undang

Nomor 12 Tahun 1991 Tentang Hak Cipt

Undang - undang Nomor 14 Tahun 2001 tentang Undang-Undang Nomor 13

Tahun 1997 Tentang Perubahan atas Undang-undang Nomor 14 Tahun 1997 tentang Perubahan atas Undang-Undang Nomor 19 Tahun 1992 Tentang Merk.

Undang - undang Nomor 30 Tahun 2000

Tentang Rahasia Dagang.

Undang - Undang Nomor 31 Tahun 2000 Tentang Desain Industri.

Undang-Undang Nomor 32 Tahun 2000 Tentang Desain Tata Letak Sirkuit Terpadu. 